\title{
NFYA wt Allele
}

National Cancer Institute

\section{Source}

National Cancer Institute. NFYA wt Allele. NCI Thesaurus. Code C104691.

Human NFYA wild-type allele is located in the vicinity of 6 p21.3 and is approximately $29 \mathrm{~kb}$ in length. This allele, which encodes nuclear transcription factor $Y$ subunit alpha protein, is involved in binding to the CCAAT motif in gene promoters. 